\title{
Identification and Learning Styles' Variation Factors for a Hybrid and Distance Learning Professional Training ODL-SPOC
}

\author{
https://doi.org/10.3991/ijet.v16i17.20851 \\ Mostafa Hamse ${ }^{(凶)}$, Said Lotfi, Mohammed Talbi \\ Hassan II University, Casablanca, Morocco \\ hamsieps@gmail.com
}

\begin{abstract}
The objective of this study is to analyze the learning styles' variation of Physical Education and Sports'(PES) trainee teachers in relation with demographic factors, type of hybrid or distance training, and technopedagogical design envisaged for designing an Open Distance Learning based on Small Private Online Courses (ODL-SPOCs) device. We used the Learning Styles Questionnaire (LSQ-Fa), an adapted and shortened version, as an instrument for measuring learning styles distributed to 65 trainee teachers in PES. We examined the effect of these independent variables: sex, age, license's type, work's experience in PES or sport, training's type, the content's form of our ODLSPOCs and instructional tutoring needs and their interaction on variations in learning styles' scores of PES trainee teachers at a threshold of $p<0.05$. The data is analyzed by ANOVA test by comparing the variables' frequencies. The results revealed that trainee teachers aged 30 and over scored higher than those aged 20 to 24 in three learning styles: reflectors, theorists and pragmatists.Moreover, trainee teachers aged 30 and over scored higher than those aged 25 to 29 in three learning styles: reflectors, theorists and pragmatists.Thus, based on ANOVA test, we found that trainee teachers' hybrid or distance training and their technical problem-solving needs have the most influence on learning style scores' variation. Based on our results, we recommend to teachers who are SPOCs' designer-tutors to identify and verify the learners' learning styles variation in order to improve performance in open distance learning.
\end{abstract}

Keywords-learning styles, ODL, trainee teachers' needs, spoc, instructional tutoring

\section{Introduction}

Currently, we are witnessing an expansion of opportunities offered by ICT (Information and Communication Technologies) in the field of education and training. Forms of online learning such as Online Distance Learning (ODL), M-Learning (Mobile learning), MOOCs (Massive Open Online Courses) and SPOCS (Small Private Online Courses) are now an integral part of training courses' modules offered to "Google generation's" students [1] at universities around the world to meet their 
teaching expectations.For example, trends in MOOCs Research show that research questions focused primarily on learning processes followed by design of MOOCs, learning experience and predictors of retention [2].In this regard, in education, the role of ICT is paramount, especially for supporting teachers in ICT integrated teaching [3].Furthermore, researches indicate that user satisfaction with e-learning never reaches the desired levels of its introduction [4-5]. Among the variables that may explain the low user satisfaction with e-learning is the mismatch between the expectations of learners and the solutions offered by this learning [6].In this perspective, several general studies on the acceptance of technology in relation to the use of Elearning have underlined the alignment that must be between the offers of online learning and learners' individual needs [7-8]. In general, previous researches emphasized the importance of taking into account the expectations and preferences of learners so that online learning can be attractive for learner, and not just a simple support. From this perspective, preferred learning styles turn out to be an educational tool allowing individualization of learning routes. In addition, they represent each individual's preferred approach or learning's mode compared to others and should be taken into consideration for better learning outcomes. It is therefore important for trainers and educators to understand different learning styles in order to be able to engage effectively in the transfer of knowledge and skills [9].

In Morocco, educational system, through the strategic vision of the 2015-2030 reform, reserves a major importance to the integration of ICT for the development and promotion of e-learning through implementation of adapted, scalable, open and innovative's devices [10]. In this context, the professional training of trainee teachers of Physical Education and Sports (PES), at Regional Center of Educational and Training Professions (RCETP) Casablanca-Settat, adhered to this vision by taking advantage of the characteristics of structuring, organization and adaptation offered by ODL systems by offering trainee teachers an ODL to complete their initial face-to-face training and develop their professional teaching skills related to planning, management and evaluation of learning in PES [11]. However, establishment of such a device requires taking into account trainees' needs and more specifically their learning styles in order to adjust this online distance training to their technopedagogical expectations. We can touch these expectations and needs in different students' preferred learning styles. They can learn well by watching, listening or reading and others by doing and moving around a practical environment.

The objective of our study is twofold, on the one hand to determine the different learning styles of the trainee teachers participating in our ODL-SPOCs' training, and on the other hand, their representations towards utility, multimedia design and educational tutoring's form of our ODL-SPOCs system.

This study was guided by the following two questions:

- What are the PES trainee teachers' learning style?

- What are the relationships among PES trainee teachers' as measured by LSQ-Fa based on gender, age, major, training type, professional experience in PES or Sport, platform's content and instructional tutoring form? 


\section{Theoretical background}

\subsection{Open distance learning}

The Commonwealth of Learning [12] defines ODL as "a system of teaching and learning characterized by separation of teacher and learner in time and/or place; [that] uses multiple media for delivery of instruction; [and] involves two-way communication and occasional face to-face meeting for tutorials and learner-learner interaction". In this regard, it represents all of the organizational arrangements that aim to provide education or learning to individuals who are distant from the service provider organization. This mode of training requires special training technology, course design, and technical communication media. Open distance learning is part of the ODL family but is positioned by the integration of information and communication technologies, adapted to individual and training's modularity.The convenience and flexibility of ODL have enabled millions of people to access higher education and this would have been an impossibility without ODL [13]. In the same vein, open distance learning (ODL) is a multidimensional concept aimed at reducing the temporal, geographical, economic, social, educational and communication distance between student and institution, the student and academics, student and tutorial and the student and peers [14]. In addition, ODL combines two forms of training, namely "open" and "distance" which focuses on expanding access to learning. ODL is characterized by its philosophy and technology. Most establishments adopting ODL aim to transcend the boundaries of the education sector while allowing students to study what they want, where they want and when they want. Thus, ODL aims to increase access to education and increase educational choices.Institutions imparting education through Open and Distance Learning (ODL) mode have been incessantly trying to gain competitiveness through development of their capabilities, especially with the increasing competition due to increase in the number of institutions with similar objectives [15].In this context,for [16] results of students' satisfaction with online learning experiences show that participants were highly satisfied with Google Hangouts the most for lecture delivery, followed by Google Classroom and LMS (Moodle) for course management and assessments.

\subsection{Learning styles}

The phrase learning styles refers to the concept that different people prefer to process information in different ways and therefore learn more effectively when they receive instruction in a way that conforms to their preferences [17]. It is also defined as "a description of attitudes and behaviors that determine an individual's preferred way of learning"[18]. Loo [19] defines learning style as "the coherent way in which the learner reacts or interacts to stimuli in learning." For our study, we adopted Honey and Mumford's [18] definition of learning style.Currently, there are more than 70 types of learning styles available, here we list some models of learning styles which are most used in scientific literature: The Felder-Silverman learning style model divides learning style into four dimensions: perception, input, processing, and under- 
standing [20].Kolb's experiential learning theory [21] divides individual learning styles into four profiles: divergent, assimilator, convergent, and accommodator. The Grasha-Riechmann learning style model investigates how learning, divides them into six types of learning styles: participant, avoidant, collaborative, competitive, independent and dependent[22].The Myers-Briggs model divides learning styles into eight profiles: extroverts, Introverts, sensors, intuitives, judgers, perceivers, feelers and thinkers [23].Based on student performance and preference in the learning process, [24] divides students into activists, reflectors, theorists and pragmatists. The following is a brief description of each style of the four styles [25]:

Activists: Activist learners like to learn by trial and error. They are open-minded and excited to try new things. They tend to act first and consider the consequences later and focus their activities on themselves.

Reflectors: reflector learners learn by observing and reflecting on what has happened. They prefer to take a step back and see their experiences from different angles. They prefer to collect data and take time to work on appropriate conclusion.

Theorist: Theorist learners prefer to think logicaly to solve problems and like analyzing and synthesizing. They value rationality and objectivity and they are passionate about basic assumptions, principles, theories, models and systems thinking.

Pragmatists: Pragmatist learners are eager to put ideas, theories and experiences. They like to get things done and act quickly and confidently on new ideas that attract them.

\subsection{ODL-SPOCs design's adaptation to learning styles}

It is essential that ODL's design takes into account students' learning styles. In order to teach more effectively in online courses, instructors need to know more about learning's differences and how to approach the variety of their students' learning styles. [26] investigate the benefits of integrating learning styles in the Web-based educational systems and offer a tool that allows the tutor and the instructional designer to interpret learner courses. Otherwise,teachers who know the differences in learning styles are better able to modify their teaching strategies and techniques in online teaching. This can help to verify resources' typology, design and instructional tutoring used in these online courses in order to create a supportive learning environment.

\section{Methods}

\subsection{Sample}

Our sample is made up of 65 trainee teachers, who have completed their professional training at Regional Center of Educational and Training Professions (RCETP) during the period 2018/2019, Physical Education and Sports (PES), for teaching at middle and high school level.

It is divided into two groups: 
- A group with hybrid training: formed by 41 trainee teachers $(63 \%)$ that we called hybrid in reference to ODL's nature envisaged. They will follow a double training: face-to-face at RCETP and an online distance training.

- A group with distant training formed by 24 trainee teachers (37\%) of 2017 training promotion who practice their profession and will follow a face-to-face training at the RCETP spread over 4 weeks of reception, training and evaluation.

\subsection{Measurement instruments}

In the present survey, we measured learning styles using the Learning Styles Questionnaire (LSQ) of Honey and Mumford (1992), a version adapted and abridged by [27], by reducing its length from 80 to 48 statements. The LSQ-Fa ("Fa" for the abbreviated French version) remains identical to the LSQ in its purpose and structure, retaining the format of the seven-point response scale. However, it differs as the length of scales, each decreasing from twenty to twelve items. With a response scale in seven points and twelve items per scales, the score on a scale therefore varies from 12 to 84 points. Based on their preferences and performance, Honey and Mumford classifie students into four styles: activists, reflectors, theorists and pragmatists.

\subsection{Data analysis}

The data are analyzed by MANOVA test by comparing variables' means, we examined the effect of the following independent variables: sex, age, training's type, majors, professional experience in PES or sport, the content's form of our ODLSPOCs and instructional tutoring's needs and their interaction on the trainee teachers' learning styles scores variation at a threshold $\mathrm{p}<0.05$. The analysis of learning styles scale's reliability is made by Cronbach's alpha. The data were processed with SPSS 26 software.

\section{$4 \quad$ Results}

\subsection{Analysis of learning styles' scale reliability}

The Cronbach's Alpha test that we used allowed to measure the four subscales' reliability containing 48 statements which are supposed to measure the same construct. In principle the values obtained vary from 0 to 1 . When the value is closer to 1 . The internal consistency between items on the same scale is higher. Thus, in our results, all calculated values of statements are higher than a threshold of 0.80 recommended by [28]. All four scales' items are sufficiently inter-correlated: the internal validity of the questionnaire is therefore satisfactory (Table 1). Indeed, we will keep all the items in our questionnaire for the following analyzes. 
Paper-Identification and Learning Styles' Variation Factors for a Hybrid and Distance Learning...

Table 1. Analysis of learning styles scale's reliability

\begin{tabular}{|l|c|c|}
\hline \multicolumn{1}{|c|}{ LSQ-Fa Scale's Learning Styles } & Items' number & Cronbach's alpha \\
\hline Activist & 12 & 0.899 \\
\hline Réflector & 12 & 0.822 \\
\hline Theorist & 12 & 0.886 \\
\hline Pragmatist & 12 & 0.902 \\
\hline Global scale & 48 & 0.818 \\
\hline
\end{tabular}

\subsection{Learning styles' variation factors}

The variation in learning style scores according to age, gender, type of training, work experience in PSE or sport, the ODL-SPOCs' content form and instructional tutoring needs, are presented in Figure 1, Figure 2 and Table 2. The analysis of style score variation's factors by MANOVA test is shown in Table 3. Table 2 displays the LSQ mean scores for all respondents.

Gender effect. The results in figure 1. show that female trainee teachers scored higher than their male counterparts in the reflector $(\mathrm{M}=69.06, \mathrm{SD}=9.15)$ and pragmatist $(\mathrm{M}=71.23, \mathrm{SD}=12.36)$ style. However, ANOVA test (table 3$)$ revealed that there are statistically significant differences between female trainee teachers $(\mathrm{M}=$ $71.23, \mathrm{SD}=12.36)$ and male trainee teachers $(\mathrm{M}=66.00, \mathrm{SD}=13.18) ;(\mathrm{F}=9.832, \mathrm{p}$ $=0.003, \eta 2=0.210)$ in the pragmatist learning style.

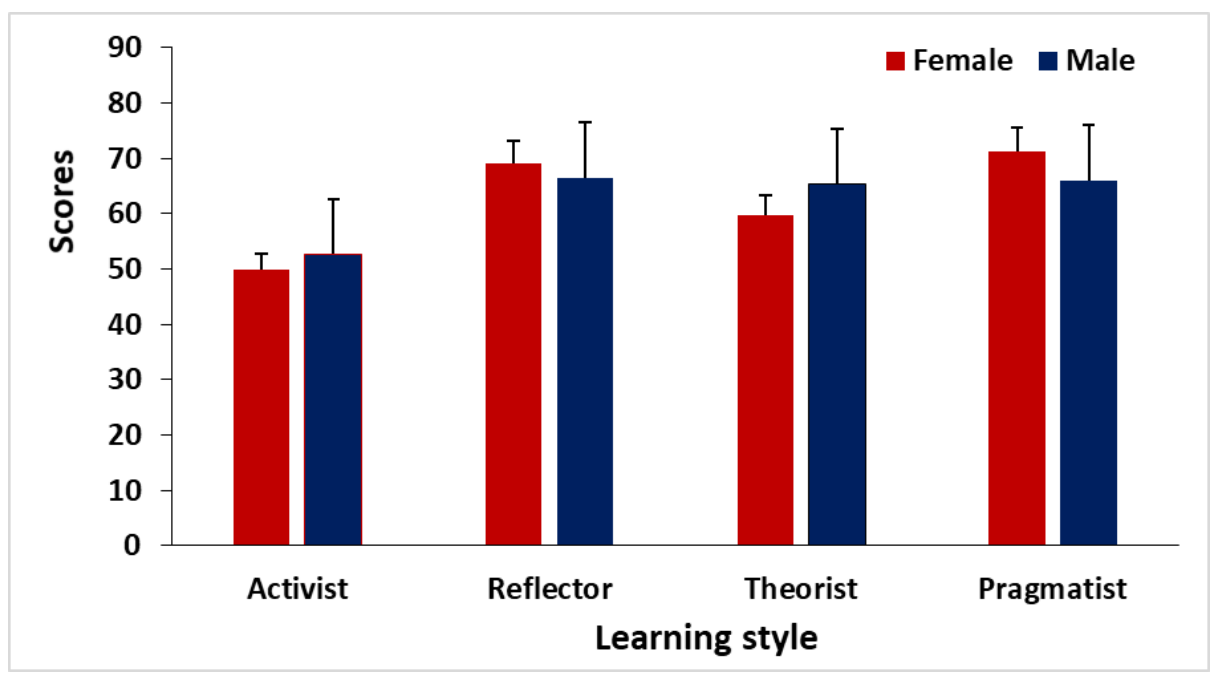

Fig. 1. Variation in learning style scores according to gender (data are presented of mean $\pm \mathrm{sd}$ )

Age effect. The results in figure 2 showed that trainee teachers aged 20 to 24 scored higher than those aged 25 to 29 in four learning styles: activist, reflector, theorist and pragmatist.Trainee teachers aged 30 and over scored higher than those aged 20 to 24 in three learning styles: reflector, theorist and pragmatist.Trainee teachers 
aged 25 to 29 scored higher than those aged 30 and over in the activist learning style. However, the MANOVA test in Table 3 shows that there are statistically significant differences between the three age groups : 20 to 24 years $(\mathrm{M}=62.40, \mathrm{SD}=18.38), 25$ to 29 years $(\mathrm{M}=53.60, \mathrm{SD}=22.16)$ and 30 years and over $(\mathrm{M}=74.40, \mathrm{SD}=10.04)$, $(\mathrm{F}=5.440, \mathrm{p}=0.008, \eta 2=0.227$,$) in the theorist learning style.$

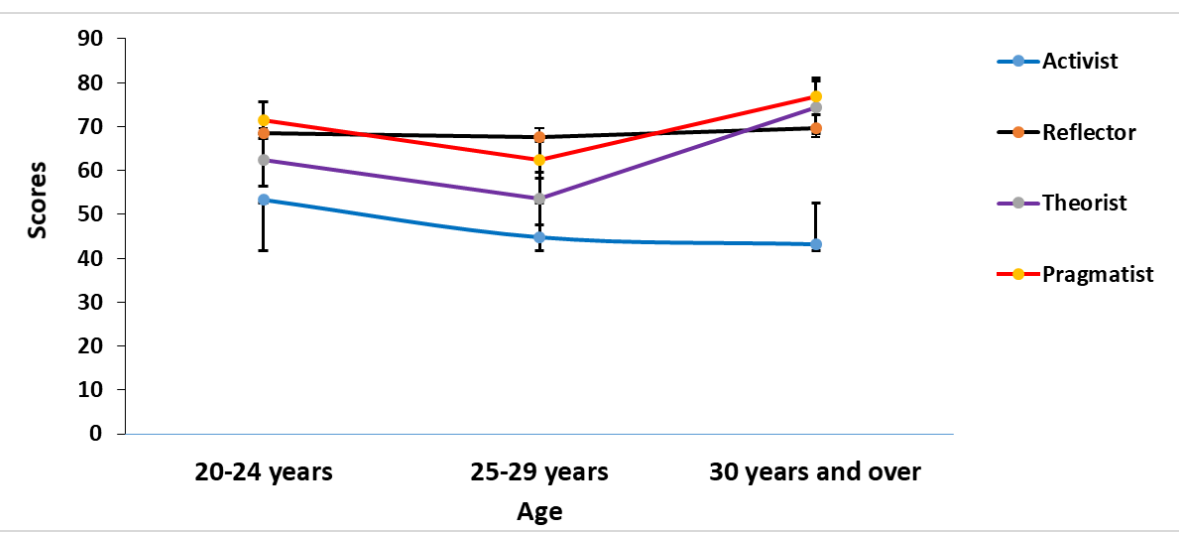

Fig. 2. Variation in learning style scores according to age (data are presented of mean $\pm \mathrm{sd}$ )

Major effect. The results in Table 2 show that trainee teachers with a professional major of teaching physical education and sport (PMTPES) obtained higher scores than those with a sport and hobbies major (SHM) and those with a qualifying professional major $(\mathrm{QPM})$ in the activist $(\mathrm{M}=53.74, \mathrm{SD}=21.06)$ and pragmatist $(\mathrm{M}=$ $70.96, \mathrm{SD}=13.00)$ learning style. SHM trainee teachers scored higher than QPM trainee teachers in all four learning styles: activist $(\mathrm{M}=51.60, \mathrm{SD}=26.56)$, reflector $(\mathrm{M}=71.20, \mathrm{SD}=6.61)$, theorist $(\mathrm{M}=73.20, \mathrm{SD}=15.44)$ and pragmatist $(\mathrm{M}=70.80$, $\mathrm{SD}=13.21)$. Moreover, the QPM trainee teachers scored higher than those of PMTPES in the theorist learning style $(M=58.67, \mathrm{SD}=20.53)$. Nevertheless, MANOVA test results in Table 3 show no statistically significant differences between the four learning styles $(\mathrm{p}>0.05)$ and the type of major obtained by trainee teachers.

Effect of training type. The results of Table 2 show that activist style's scores are significantly high by $24.66 \%$ [(56.49- 40.50) / 40.5]* 100 for trainee teachers involved in hybrid training compared to those of distanced training respectively $56,49 \pm$ 21.37 vs $40.50 \pm 21.24(\mathrm{~F}=17.181, \mathrm{p}=0.000, \eta 2=0.317)$. Thus, the pragmatist style's scores are significantly high by $8.71 \%$ [(73.50- 67.61) / 67.61] $* 100$ for trainee teachers involved in distance training compared to those of hybrid training respectively $73.50 \pm 13.24$ vs $67.61 \pm 11.85(\mathrm{~F}=0.215, \mathrm{p}=0.047, \eta 2=0.228)$. Nevertheless, the ANOVA test (Table 3 ) shows that there are statistically significant differences between the type of hybrid $(M=56.49, S D=21.37)$ and distance $(M=40.50$, $\mathrm{SD}=21.24),(\mathrm{F}=17.181, \mathrm{p}=0.000, \eta 2=0.317)$ training in the activist learning style. There are also statistically significant differences between the type of hybrid (M $=67.61, \mathrm{SD}=11.85)$ and distance $(\mathrm{M}=73.50, \mathrm{SD}=13.24),(\mathrm{F}=0.215, \mathrm{p}=0.047, \eta 2$ $=0.228$ ) training in pragmatist learning style. 
Effect of professional experience: PES vs Sport. The results in Table 2 show that trainee teachers who had experience in PES or sport scored higher than those with no experience in learning styles: reflector $(M=69.94, S D=9.48)$, theorist $(M=68.25$, $\mathrm{SD}=21.79)$ and pragmatist $(\mathrm{M}=72.75, \mathrm{SD}=10.25)$, while trainee teachers who had no experience in PES or sport scored higher than those with experience in activist learning style $(\mathrm{M}=51.92, \mathrm{SD}=21.69)$. However, MANOVA test results in Table 3 show no statistically significant differences between the four learning styles: activist $(F=0.702, p=0.407, \eta 2=0.019$,$) , reflector (F=0.017, p=0.896, \eta 2=0.000$,$) ,$ theorist $(\mathrm{F}=0.161, \mathrm{p}=0.690, \eta 2=0.004)$ and pragmatist $(\mathrm{F}=0.989, \mathrm{p}=0.326, \eta 2=$ 0.026 ,) of trainee teachers based on their experiences in PES or sport.

Effect of platform content. The results show that trainee teachers preferring structured texts obtained higher scores than those preferring video, images, diagrams and mixed capsules in activist $(\mathrm{M}=66.00, \mathrm{SD}=25.46)$ and pragmatist $(\mathrm{M}=72.00, \mathrm{SD}=$ 0.00 ) learning style. While trainee teachers preferring video clips obtained higher scores than those choosing other content's forms in reflector learning style $(\mathrm{M}=$ $71.25, \mathrm{SD}=8.07)$. On the other hand, trainee teachers preferring a blended content form scored higher than other trainee teachers in theorist learning style $(\mathrm{M}=62.93$, $\mathrm{SD}=21.26$ ). However, MANOVA test results in Table 3 show no statistically significant differences between the four learning styles ( $p>0.05)$ and online content's form preferred.

Effect of platform content. The results of Table 2 show that the trainee teachers declaring their need for highlighting the educational objectives obtained a higher score compared to those desiring other instructional tutoring forms in pragmatist learning style $(\mathrm{M}=68.00, \mathrm{SD}=12.09))$.In addition, respondents desiring as needed group's conflicts resolution scored highest compared to those desiring other tutoring form in pragmatist learning style $(\mathrm{M}=70.59, \mathrm{SD}=11.91)$ and at the same time, they obtained the lowest score in activist learning style $(\mathrm{M}=51.53, \mathrm{SD}=26.42)$. In addition, trainee teachers declaring their need to have an evaluation of their work obtained higher scores compared to those desiring other tutoring forms in reflector $(\mathrm{M}=$ $68.77, \mathrm{SD}=9.00)$ and pragmatist $(\mathrm{M}=71.45, \mathrm{SD}=10.13)$ learning style. For respondents who expressed other form of instructional tutoring needs, we find that they obtained lower scores than those desiring other forms in activist $(\mathrm{M}=42.00, \mathrm{SD}=$ $25.46)$, theorist $(\mathrm{M}=54.00, \mathrm{SD}=8.49)$ learning style. Nevertheless, the MANOVA test (Table 3 ) revealed that there are statistically significant differences between technical problem solving $(\mathrm{M}=48.55, \mathrm{SD}=22.26),(\mathrm{F}=1.712, \mathrm{p}=0.0201, \eta 2=0.106)$ and activist learning style. There are also statistically significant differences between technical problem solving variable and pragmatist learning style $(\mathrm{M}=69.55, \mathrm{SD}=$ 13.34), $(\mathrm{F}=0.152, \mathrm{p}=0.034, \eta 2=0.005)$. Moreover, we found from these same results of MANOVA test that there are also statistically significant differences between work evaluation's variable $(\mathrm{M}=71.45, \mathrm{SD}=10.13),(\mathrm{F}=1.612, \mathrm{p}=0.034$, $\eta 2=0.151)$ and pragmatist learning style. 
Paper-Identification and Learning Styles' Variation Factors for a Hybrid and Distance Learning...

Table 2. Variation in learning style scores according to major, type of training, experience in PES, content's form and type of instructional tutoring

\begin{tabular}{|c|c|c|c|c|c|c|c|c|c|c|c|c|c|}
\hline \multirow{2}{*}{\multicolumn{2}{|c|}{ Parameters }} & \multicolumn{3}{|c|}{ Activist } & \multicolumn{3}{|c|}{ Reflector } & \multicolumn{3}{|c|}{ Theorist } & \multicolumn{3}{|c|}{ Pragmatist } \\
\hline & & $N$ & Mean & $S d$ & $N$ & Mean & $S d$ & $N$ & Mean & $S d$ & $N$ & Mean & $S d$ \\
\hline \multirow{4}{*}{ Major } & PMTPES & 23 & 53.74 & 21.06 & 23 & 70.61 & 8.70 & 23 & 56.87 & 19.56 & 23 & 70.96 & 13.00 \\
\hline & SHM & 10 & 51.60 & 26.56 & 10 & 71.20 & 6.61 & 10 & 73.20 & 15.44 & 10 & 70.80 & 13.21 \\
\hline & QPM & 18 & 51.33 & 25.31 & 18 & 65.44 & 8.99 & 18 & 58.67 & 20.53 & 18 & 68.67 & 14.14 \\
\hline & Others & 14 & 43.71 & 19.75 & 14 & 66.36 & 8.55 & 14 & 63.43 & 17.88 & 14 & 68.57 & 10.97 \\
\hline \multirow{2}{*}{$\begin{array}{l}\text { Type of } \\
\text { training }\end{array}$} & Distanced & 24 & 40.50 & 21.24 & 24 & 71.79 & 7.35 & 24 & 67.50 & 19.75 & 24 & 73.50 & 13.24 \\
\hline & Hybrid & 41 & 56.49 & 21.37 & 41 & 66.34 & 8.71 & 41 & 57.66 & 18.13 & 41 & 67.61 & 11.85 \\
\hline \multirow{2}{*}{$\begin{array}{c}\text { Profes- } \\
\text { sional } \\
\text { experience } \\
\text { in PES Vs } \\
\text { Sport } \\
\end{array}$} & $\begin{array}{l}\text { Aucune experi- } \\
\text { ence }\end{array}$ & 49 & 51.92 & 21.69 & 49 & 67.84 & 8.40 & 49 & 59.02 & 18.14 & 49 & 68.82 & 13.37 \\
\hline & With experience & 16 & 46.50 & 25.88 & 16 & 69.94 & 9.48 & 16 & 68.25 & 21.79 & 16 & 72.75 & 10.25 \\
\hline \multirow{4}{*}{$\begin{array}{c}\text { Form of } \\
\text { platform's } \\
\text { content }\end{array}$} & Structured text & 2 & 66.00 & 25.46 & 2 & 64.50 & 4.95 & 2 & 60.00 & 16.97 & 2 & 72.00 & 0.00 \\
\hline & Video capsules & 12 & 55.00 & 25.82 & 12 & 71.25 & 8.07 & 12 & 58.00 & 14.32 & 12 & 65.00 & 14.88 \\
\hline & $\begin{array}{l}\text { Pictures and } \\
\text { diagrams }\end{array}$ & 10 & 50.40 & 24.53 & 10 & 67.80 & 8.27 & 10 & 58.80 & 18.29 & 10 & 70.80 & 15.44 \\
\hline & Mixed & 41 & 48.59 & 21.63 & 41 & 67.83 & 9.07 & 41 & 62.93 & 21.26 & 41 & 70.83 & 11.64 \\
\hline \multicolumn{2}{|c|}{$\begin{array}{c}\text { Explain certain concepts in } \\
\text { the course }\end{array}$} & 51 & 48.94 & 23.25 & 51 & 68.16 & 9.22 & 51 & 61.41 & 20.31 & 51 & 70.82 & 12.76 \\
\hline \multicolumn{2}{|c|}{$\begin{array}{l}\text { Highlight the courses' peda- } \\
\text { gogic objectives }\end{array}$} & 24 & 54.00 & 21.81 & 24 & 66.54 & 9.03 & 24 & 61.00 & 18.70 & 24 & 68.00 & 12.09 \\
\hline \multicolumn{2}{|c|}{ Solve technical problems } & 44 & 48.55 & 22.26 & 44 & 67.66 & 9.36 & 44 & 58.09 & 20.20 & 44 & 69.55 & 13.34 \\
\hline \multicolumn{2}{|c|}{ Solve group's conflicts } & 17 & 51.53 & 26.42 & 17 & 68.88 & 10.00 & 17 & 52.24 & 18.95 & 17 & 70.59 & 11.91 \\
\hline \multicolumn{2}{|c|}{ Have the work's evaluation } & 22 & 50.18 & 23.90 & 22 & 68.77 & 9.00 & 22 & 63.82 & 20.41 & 22 & 71.45 & 10.13 \\
\hline \multicolumn{2}{|c|}{ Other needs } & 2 & 42.00 & 25.46 & 2 & 62.00 & 2.83 & 2 & 54.00 & 8.49 & 2 & 60.00 & 0.00 \\
\hline
\end{tabular}

Table 3. Analysis of variation factors' learning styles scores by MANOVA

\begin{tabular}{|l|c|c|c|c|}
\hline \multirow{2}{*}{ Effect } & \multicolumn{4}{|c|}{ Learning styles } \\
\cline { 2 - 5 } & Activist p-value & Reflector p-value & Theorist p-value & Pragmatist p-value \\
\hline Age & $\mathrm{ns}$ & $\mathrm{ns}$ & 0.008 & $\mathrm{~ns}$ \\
\hline Gender & $\mathrm{ns}$ & $\mathrm{ns}$ & $\mathrm{ns}$ & 0.003 \\
\hline Type training & 0.000 & $\mathrm{~ns}$ & $\mathrm{~ns}$ & 0.047 \\
\hline Major & $\mathrm{ns}$ & $\mathrm{ns}$ & $\mathrm{ns}$ & $\mathrm{ns}$ \\
\hline Experience in PES or Sport & $\mathrm{ns}$ & $\mathrm{ns}$ & $\mathrm{ns}$ & $\mathrm{ns}$ \\
\hline Content's form & $\mathrm{ns}$ & $\mathrm{ns}$ & $\mathrm{ns}$ & $\mathrm{ns}$ \\
\hline Explain concepts & $\mathrm{ns}$ & $\mathrm{ns}$ & $\mathrm{ns}$ & $\mathrm{ns}$ \\
\hline $\begin{array}{l}\text { Highlight the courses' } \\
\text { objectives }\end{array}$ & $\mathrm{ns}$ & $\mathrm{ns}$ & $\mathrm{ns}$ & 0.034 \\
\hline Solve technical problems & 0.020 & $\mathrm{~ns}$ & $\mathrm{~ns}$ & $\mathrm{~ns}$ \\
\hline Solve group's conflicts & $\mathrm{ns}$ & $\mathrm{ns}$ & $\mathrm{ns}$ & 0.034 \\
\hline Work's evaluation & $\mathrm{ns}$ & $\mathrm{ns}$ & $\mathrm{ns}$ & $\mathrm{ns}$ \\
\hline Others & & & & \\
\hline
\end{tabular}




\section{Discussion}

The aim of our study is to identify the learning style preferences of PES trainee teachers using LSQ. We also examine whether there are statistically significant differences in these preferred learning styles related to their demographic, academic characteristics, content design needs, and tutoring's form desired. Indeed, we analyzed learning style scores' variation according to age, sex, type of training, experience in PES, content's form and type of instructional tutoring, and also the variation in scores for these styles by MANOVA test.

\subsection{Gender effect}

The first result presenting the variation in learning styles related to respondents' gender showed that female trainee teachers scored higher than their male counterparts in two learning styles: reflector and pragmatist. Thus the MANOVA test showed the presence of statistically significant differences between female and male sex and preferred learning styles. These results agree with the claims that learning styles differ by gender.Female gender trainee teachers prefer non-traditional learning and classroom environments, while male gender trainee teachers prefer traditional analytical learning and classroom environments [29]. Ramayah et al. [30] report that women learn more often visually and orally than men. Holtbrügge and Mohr [31] argue that male students prefer active experimentation to reflective observation more than female students. These findings contradict a number of previous studies which have found no impact of gender on students' learning style preferences [32-38]. In this regard, we suggest presenting a varied distance learning content adapted to meet the both male and female needs.

\subsection{Age effect}

The second result concerns the variation in learning style relative to trainee teachers' age. Indeed, our results showed that all of the trainee teachers $(N=45)$ who were 20 to 24 years old had higher scores than their counterparts aged 25 to 29 years in the four learning styles, which showed that they are predisposed to join us in a structured training content, organized and adapted to these four styles. Thus, our results in Table 3 also showed that there are statistically significant differences between the three age groups and theorist learning style. The results corroborate the conclusions of [39] who suggested that age influences preferences in terms of learning style, as well as those of [40] who stated that there is a relationship between learning styles and age and also the conclusions of [41] who found significant relationships between certain learning styles and students age. Nonetheless, these findings contrast with a number of previous studies that have found no relation between age and student learning style preferences [42-37-43]. Faced with these results, we propose to design a training content that emphasizes models and summary sheets meeting the needs of the learning style on the one hand and on the other hand to design online training sequences taking into 
Paper-Identification and Learning Styles' Variation Factors for a Hybrid and Distance Learning...

account the characteristics of the four learning styles in relation with trainee teachers age.

\subsection{Training type's effect}

The third result of our study presents the learning styles' variation related to type of training received: hybrid or distance learning. Indeed, we have noted high scores obtained by hybrid trainee teachers in activist learning style. This is probably because activist students tend to learn best as a member of a team. They like solving problems and facing new challenges and experiences [44]. These results are supported by [45] which say that hybrid teaching, for its asynchronous teaching methods based on technology and traditional teaching methods, give students more control over their own learning and promote greater interaction and cognitive engagement. Furthermore, for [46], blended teaching can improve all learning styles. At the same time, the results showed that trainee teachers involved in distance learning have significantly higher scores compared to those in hybrid training in the pragmatist learning style. Which can be explained by the fact that this profile of pragmatist students probably learn best by understanding real-world application and trying things out once they usually have a clear structured plan with a definable goal [44]. These results clearly show that the nature of the training received: hybrid or distance learning influences learning styles' variation. This conclusion is supported by [47] who stipulates that one of the means to improve online course's quality is tailoring and delivering teaching material to a specific learning style. However, previous research results have found no influence of learning styles on student performance only in online learning. In the first study, [48] found that the four learning styles (activist - reflector, sensory - intuitive, visual verbal, sequential - global) did not influence the students' learning experience and learning outcomes during the implementation of e-learning. Another study [49] showed that cognitive style did not affect learning and learner satisfaction. Moreover, in 2015, researchers mentioned that different learning styles can affect students' success in online courses [50]. Based on these results presented above, we recommend to teacher-designers of online courses to vary their teaching methods, techniques and instruments used in their hybrid or distanced online courses in order to meet the different learners' learning styles and therefore maximize learning performance.

\subsection{Major and PES or sport's effect}

The fourth result of our study represents the experience of our trainee teachers in terms of major received and work experience in PES or Sport. Indeed, for the major received, we observed the learning styles of respondents vary in major function obtained: either PMTPES, SHM or QPM. Furthermore, MANOVA test (Table 3) showed that there are no statistically significant differences between the four learning styles ( $p>0.05)$ and major effect. These results contradict those of [35] who stated that type of training had no significant impact on learning styles' preferences. In parallel, the results in Table 2 showed that trainee teachers who had work experience in PES or sport obtained higher scores than those who had no experience in these learn- 
ing styles: reflector, theorist and pragmatist. However, MANOVA test results in Table 3 showed no statistically significant differences between the four learning styles and the respondents' sport experience. This is in line with results of [35].

\subsection{Platform content's effect}

The fifth result of our study represents the learning styles' variation depending on content's form variables of our platform. Indeed, trainee teachers preferring structured texts obtained higher scores than those preferring video capsules, images, diagrams and mixed in activist and pragmatist learning styles. These results confirm that structured texts in the form of training modules with chapters and sub-chapters are more desired by our respondents than other forms. These same results support those of [51] and [52] who state that the modules are more suited to students with more mature critical thinking skills, to understand the module without the representation of images, graphs, diagrams, tables, etc. However, results in Table 3 show no statistically significant differences between the four learning styles ( $>0.05)$ and the preferred form of online content; which is opposed to the conclusions of [53] and [54] affirming the existence of an interaction between the learning supports and learning styles on the learning achievements. Soylu and Akkoyunlu [55] and Fan and Xiao [56] in their research also conclude that there is an interaction between learning materials and learning styles on the students' learning outcomes. The results of this research are supported by [57] and [58] who conclude that there is an interaction between learning supports and learning styles by influencing the ability to understand learning materials that has an impact on student achievement.

\subsection{Instructional tutoring form's effect}

The last result of our study presents the variation of learning styles in relation to instructional tutoring type desired by trainee teachers. Indeed, they want to know their pedagogical objectives since they obtained higher scores compared to other forms of instructional tutoring in the pragmatist learning style. These results show that these respondents want a detailed plan of their online course in the form of pedagogic objectives that guide and facilitate their learning. According to [59], effective design, facilitation and direction of cognitive and social processes are the activities that define the presence and effectiveness of teachers in online courses. This leads us as a SPOC trainer-tutor to schedule courses organized by themes and chapters and finalized by time-bound pedagogic objectives to meet the trainee teachers needs who are pragmatist learning style. Thus, respondents requesting group conflict resolution obtained the highest score compared to those desiring other form of pragmatist learning style tutoring, which shows that this profile of trainee teachers need a healthy work climate based on collaboration and interpersonal interaction. These results are supported by [60] who believe that an interactive and cohesive environment that includes group work, regular assignments, and strong feedback is necessary for success. Graham and al. [61] assert that a "well-designed discussion facilitates meaningful cooperation". Levy [62] found that collaborative activities as well as other interactions such as read- 
ing student messages were appreciated by students. However, these results contradict the conclusions of [63] which characterize the learning activities of a reflector learning style by self-learning aspect. Moreover, the results show that trainee teachers who have a predominantly reflector and pragmatist learning style obtained the highest scores on the need to have their activities evaluated during the planned online courses. These results show that in e-learning, these two styles require knowing their degree of acquisition as progressing in course. In addition, results in Table 3 show that there are statistically significant differences between trainee teachers' need to solve technical problems and two learning styles: activist and pragmatist. This can be explained by their need to challenge new ideas in relation to their learning activities. Elkaseh et al. [64] support these results by describing the activist learning style through nonbiased involvement in new experiences and the pragmatist style through the desire to try new techniques in practice.

\section{Conclusion}

This study explored learning style preferences of PES trainee teachers using LSQ. It also verified whether there are statistically significant differences between these preferred learning styles and demographic, types of hybrid or distance learning, platform design and desired form of educational tutoring variables. Indeed, based on research and discussion, we can conclude that the four learning styles vary according to these variables.In fact,trainee teachers aged 30 and over scored higher than those aged 20 to 24 in three learning styles: reflector, theorist, and pragmatist.Also, trainee teachers aged 30 and over scored higher than those aged 25 to 29 in these learning styles: reflector, theorist, and pragmatist. Furthermore, there are also statistically significant differences between the type of hybrid and distance learning in the activist learning style and also statistically significant differences between the type of hybrid and distance learning in the pragmatist learning style. Trainee teachers preferring structured texts scored higher than those preferring video, images and diagrams and blended capsules in the activist and pragmatist learning styles. Moreover, theorist and pragmatist trainee teachers require more work's evaluation from their instructional tutor than other two learning styles. Based on MANOVA test, there is a significant dependency relationship between these five variables: Age, gender, type of training received, technical problem solving and evaluation of achievements and learning styles. The type of training of trainee teachers and their technical problem-solving needs most influence the variation in learning style scores.

To conclude, we recommend to teachers who are SPOCs' designer-tutors to identify and verify their learners' learning styles variation in order to design and improve the quality and performance of their open distance learning.

The study has some limitations namely: our sample is made up of only 65 trainee teachers who were in vocational training at Regional Center of Educational and Training Professions (RCETP) in Casablanca city, which questions the generalizability of the findings to other RCETP in Morocco. Then, we cannot rely only on LSQ-Fa's 
questionnaires as a benchmark to design an online distance learning device, other learning style questionnaires are possible.

Future researches could be extended to PES trainee teachers in other RCETP in Morocco to compare and contrast. Also, the study could be extended by including a teaching styles survey for teacher trainers or the ODL course designers to determine their teaching styles and investigate if there was a match or mismatch of the learning styles in the training.

\section{$7 \quad$ Acknowledgment}

The authors would like to thank the director of RCETP Casablanca-Settat and PES student-teachers who enthusiastically participated in the different phases of our study.

\section{References}

[1] Chankova, Mariya.(2020). The Google generation use of the multimedia environment for academic purposes. A qualitative approach. The Digital Scholar: Academic Communication in Multimedia Environment, vol. 153, p. 153.

[2] Abdelghani, B. (2020). Trends in MOOCs Research: Analysis of Educational Technology Journals. International Journal of Emerging Technologies in Learning (iJET), 15(17), 4768. https://doi.org/10.3991/ijet.v15i17.14637

[3] Razak, N., Ab Jalil, H., \& Ismail, I. (2019). Challenges in ICT integration among Malaysian public primary education teachers: The roles of leaders and stakeholders. International Journal of Emerging Technologies in Learning (iJET), 14(24), 184-205. https://doi.org/ 10.3991/ijet.v14i24.12101

[4] Bellinger, Alan.(2007)."E-learning: today and tomorrow What do e-learning and remarriage have in common." Training journal-ely pp. 27.

[5] Westbrook, Vivienne.(2006).The virtual learning future. Teaching in Higher Education, vol. 11, no. 4, pp. 471-482. https://doi.org/10.1080/13562510600874276

[6] Toni Mohr, Alexander, Holtbrugge, Dirk, et Berg, Nicola. (2012).Learning style preferences and the perceived usefulness of e-learning. Teaching in Higher Education, vol. 17, no. 3, pp. 309-322. https://doi.org/10.1080/13562517.2011.640999

[7] Hashim, Raemah Abdullah, Loo, Sin Chun, Harun, Yanty Roslinda, et al.(2019). Acceptance and usage, social influences, instructor's presence and performance among learners in an ODL institution. ASEAN Journal of Open \& Distance Learning (AJODL), vol. 11 , no 1, p. 52-64.

[8] Mathew, Ivy Rose. Learner Centered e-Interactions: An Exploration of Context and Practicality that Influences e-Learning Experience.(2020).International Journal on E-Learning, vol. 19, no 3, p. 229-241.

[9] Olivos, Pablo, Santos, Antonio, Martin, Sergio, et al. (2016). The relationship between learning styles and motivation to transfer of learning in a vocational training programme. suma psicológica, vol. 23, no 1, p. 25-32. https://doi.org/10.1016/j.sumpsi.2016.02.001

[10] Conseil supérieur de l'éducation de la formation et de la recherche scientifique.(2015). Pour une école de l'équité, de la qualité et de la promotion: une vision stratégique dela réforme 2015-2030. https://doi.org/10.4000/books.oep.1724 
Paper-Identification and Learning Styles' Variation Factors for a Hybrid and Distance Learning...

[11] Unité Centrale de la Formation des Cadres (UCFC), Curriculum d'éducation physique et sportive; Filière de Qualification des Professeurs du Secondaire Qualifiant.(2012).

[12] Commonwealth of Learning.(2015).Open and distance learning: Key terms and definitions.

[13] Sharma, Ramesh C., Kawachi, Paul, et Bozkurt, Aras.(2019) Exploring Changing Perspectives in Distance Education. Asian Journal of Distance Education, vol. 14, no 1, p. 1-6.

[14] UNISA, Policy on open and distancelearning.(2008).

[15] Kant, Nikhil.(2019).Competitiveness in ODL from Stakeholders' Perspective: A Review and Research Agenda. Turkish Online Journal of Distance Education, vol. 20, no 3, p. 5972. https://doi.org/10.17718/tojde.598221

[16] Almusharraf, N., \& Khahro, S. (2020). Students Satisfaction with Online Learning Experiences during the COVID-19 Pandemic. International Journal of Emerging Technologies in Learning (iJET), 15(21), 246-267. https://doi.org/10.3991/ijet.v15i21.15647

[17] Pashler, Harold, Mcdaniel, Mark, Rohrer, Doug, et al. (2008).Learning styles: Concepts and evidence. Psychological science in the public interest, vol. 9, no 3, p. 105-119. https://doi.org/10.1111/i.1539-6053.2009.01038.x

[18] Honey, Peter, and Alan Mumford. "The manual of learning styles," (1992).

[19] Loo, Robert.(2002). The distribution of learning styles and types for hard and soft business majors. Educational Psychology, vol. 22, no. 3, pp. 349-360. https://doi.org/10.1080/014 43410220138566

[20] Jeyakumar, G., et al. "A prototype for student learning style modelling using FelderSilverman learning style model." (2016).Proceedings of International Conference on Smart Structures \& Systems, pp. 178-182.

[21] Kolb, Alice Y.(2005). The Kolb learning style inventory-version 3.1 technical specifications. Boston, MA: Hay Resource Direct, 2005, vol. 200, no. 72, pp. 166-171.

[22] Baykul, Y., Gürsel, M., Sulak, H., Ertekin, E., Dülger, O., Aslan, Y., \& Büyükkarc1, K.(2010).A Validity and Reliability Study of Grasha-Riechmann Student Learning Style Scale. International Journal of Educational and Pedagogical Sciences, 4(3), 323-330.

[23] Salter, D. W., Evans, N. J., \& Forney, D. S.(2006).A longitudinal study of learning style preferences on the Myers-Briggs type indicator and learning style inventory. Journal of College Student Development, 47(2), 173-184. https://doi.org/10.1353/csd.2006.0022

[24] Swailes, S., \& Senior, B.(1999).The dimensionality of Honey and Mumford's learning styles questionnaire.International Journal of Selection and Assessment, 7(1), 1-11. https://doi.org/10.1111/1468-2389.00099

[25] Honey, P. and Mumford, A.(1999).Understanding Your Learning Styles, Psych Press, Australia Vol. 2, pp. 4-5.

[26] Bentaib, M., Aitdaoud, M., Namir, A., \& Talbi, M. Adaptive Help System Based on Learners 'Digital Traces' and Learning Styles.International Journal of Emerging Technologies in Learning (iJET), p.288. https://doi.org/10.3991/ijet.v16i10.19839

[27] Fortin, G., Chevrier, J., \& Amyot, É.(1997).Adaptation française du Learning Styles Questionnaire de Honey et Mumford. Mesure et évaluation en éducation, 19(3), 95- 118.

[28] Peterson, Robert A.(1995).Une méta-analyse du coefficient alpha de Cronbach. Recherche et Applications en Marketing (French Edition), vol. 10, no. 2, pp. 75-88. https://doi.org/ $10.1177 / 076737019501000204$

[29] Jones, Cheryl, Reichard, Carla, et Mokhtari, Kouider.(2003). are students' learning styles discipline specific?. Community College Journal of Research \&Practice, vol. 27, no. 5, pp. 363-375. https://doi.org/10.1080/713838162 
Paper-Identification and Learning Styles' Variation Factors for a Hybrid and Distance Learning...

[30] Ramayah, Malarvilly, Sivanandan, Premagowrie, Nasrijal, Neliza Hilmy, et al.(2009).Preferred learning style: Gender influence on preferred learning style among business students. Journal of US-China Public Administration, vol. 6, no. 4, pp. 65-78.

[31] Holtbrügge, D., \& Mohr, A. T.(2009).Learning style preferences of management students: A cross-cultural perspective. Working Paper. University of Erlangen- Nuremberg, University of Bradford.

[32] Pallapu, P.(2008).An exploratory study of undergraduate students' learning styles (Doctoral dissertation).

[33] Oravcova, Jitka.(2009).Learning styles of university students in relation to educational methods. The New Educational Review, vol. 19, no. 3/4, pp. 72-82.

[34] Gündüz, N. and Özcan, D.(2010)."learning styles of students from different cultures and studying in Near East University”, Procedia Social and Behavioral Sciences, vol. 9 no. 4 , pp. 5-10. https://doi.org/10.1016/j.sbspro.2010.12.107

[35] Raju, G.P.(2011)."Determining the learning styles of management students in India using Honey and Mumford learning style questionnaire", BVIMSR's Journal of Management Research, vol. 3 no. 1, pp. 1-16.

[36] Naik, B. and Girish, V.G.(2012). "An investigation of the learning styles of South Korean business students", Asia-Pacific Journal of Business, vol. 3 no. 1, pp. 1-9.

[37] Gappi, L. L.(2013) Relationships between learning style preferences and academic performance of students. International Journal of Educational Research and Technology, 4(2), 70-76.

[38] Biabani, Miriam et Izadpanah, Siros.(2019).The Study of Relationship between Kolb's Learning Styles, Gender and Learning American Slang by Iranian EFL Students. International Journal of Instruction, vol. 12, no 2, p. 517-538. https://doi.org/10.29333/iji.2019 $.12233 \mathrm{a}$

[39] Kayes, D.C.(2005)."Internal validity and reliability of Kolb's learning style Inventory Version 3 (1999)", Journal of Business and Psychology, vol. 20 no. 2, pp. 249-257. https://doi .org/10.1007/s10869-005-8262-4

[40] Seymour, R. and West-Burnham, J.(2007). "Learning styles and education management: part one", International Journal of Education Management, vol. 3 no. 4, pp. 19-25.

[41] Fleming, S., McKee, G. and Huntley-Moore, S.(2011).“Undergraduate nursing students' learning styles: a longitudinal study”, Nurse Education Today, vol. 31 no. 2, pp. 444-449. https://doi.org/10.1016/j.nedt.2010.08.005

[42] Pallapu, Prasanthi.(2008).An exploratory study of undergraduate students' learning styles. Diss.

[43] Yousef, D.A.(2014). "Learning styles preferences of undergraduate business students: a study in the faculty of business and economics at the UAE University (UAEU)", Journal of International Business Education, vol. 9, pp. 211-234. https://doi.org/10.1108/qae-012014-0004

[44] Honey, Peter, and Alan Mumford.(2000).The learning styles helper's guide. Maidenhead: Peter Honey Publications.

[45] Allen, I. Elaine, and Jeff Seaman.(2007). Making the grade: Online education in the United States, 2006. Sloan Consortium. PO Box 1238, Newburyport, MA 01950.

[46] Wichadee, Saovapa.(2013).Facilitating students' learning with hybrid instruction: A comparison among four learning styles. Electronic Journal of Research in Educational Psychology, vol. 11, no. 1, pp. 99-116. https://doi.org/10.25115/ejrep.v11i29.1559

[47] Verhun, V.(2019). Identification and Analysis of Learning Styles of MOOC Students. ECONTECHMOD: An International Quarterly Journal on Economics of Technology and Modelling Processes, vol. 8. 
Paper-Identification and Learning Styles' Variation Factors for a Hybrid and Distance Learning...

[48] Choi, Ikseon, LEE, Sang Joon, et Kang, Jeongwan.(2009). Implementing a case-basedelearning environment in a lecture-oriented anaesthesiology class: Do learning styles matter in complex problem solving over time?. British Journal of Educational Technology, vol. 40, no. 5, pp. 933-947. https://doi.org/10.1111/j.1467-8535.2008.00884.x

[49] Eyuboglu, Filiz et Orhan, Feza.(2011). Paging and scrolling: Cognitive styles in learning from hypermedia. British Journal of Educational Technology, vol. 42, no. 1, pp. 50-65. https://doi.org/10.1111/j.1467-8535.2009.00998.x

[50] Chang, Ray I., Hung, Yu Hsin, et Lin, Chun Fu.(2015). Survey of learning experiences and influence of learning style preferences on user intentions regarding MOOC s. British Journal of Educational Technology, vol. 46, no. 3, pp. 528-541. https://doi.org/10.1111/bjet.12 $\underline{275}$

[51] Sejpal, K.(2013).Modular method of teaching. International Journal for Research in Education Vol. 2,(2), (IJRE) ISSN: 2320-091X.

[52] Powell, Thomas E., Boomgaarden, Hajo G., DE Swert, Knut, et al.(2015).A clearer picture: The contribution of visuals and text to framing effects. Journal of communication, vol. 65 , no. 6 , pp. 997-1017. https://doi.org/10.1111/jcom.12184

[53] Smith, Stephen M. et Woody, Paul C.(2000).Interactive effect of multimedia instruction and learning styles. Teaching of psychology, vol. 27, no. 3, pp. 220-223. https://doi.org/ $\underline{10.1207 / \mathrm{s} 15328023 \text { top2703 } 10}$

[54] Surjono, Herman Dwi.(2015).The effects of multimedia and learning style on student achievement in online electronics course. Turkish Online Journal of Educational Technology-TOJET, vol. 14, no. 1, pp. 116-122.

[55] Yilmaz-Soylu, Meryem et Akkoyunlu, Buket.(2009). The Effect of Learning Styles on Achievement in Different Learning Environments. Turkish Online Journal of Educational Technology-TOJET, vol. 8, no. 4, pp. 43-50.

[56] Fan, Kuo-Kuang, Xiao, Peng-wei, et SU, Chungho.(2015).The effects of learning styles and meaningful learning on the learning achievement of gamification health education curriculum. Eurasia Journal of Mathematics, Science and Technology Education, vol. 11, no. 5, pp. 1211-1229. https://doi.org/10.12973/eurasia.2015.1413a

[57] Wanpen, Supatra.(2013).The relationship between learning styles and the social network use of tertiary level students. Procedia-Social and Behavioral Sciences, vol. 88, pp. 334339. https://doi.org/10.1016/j.sbspro.2013.08.514

[58] Rahadian, Raditya Bayu et Budiningsih, C. Asri.(2018). What are the suitable instructional strategy and media for student learning styles in middle schools? arXiv preprint arXiv:1801.05024.

[59] Shea, P., Li, C. S., \& Pickett, A.(2006).A study of teaching presence and student sense of learning community in fully online and web-enhanced college courses. The Internet and higher education, 9(3), 175-190. https://doi.org/10.1016/j.iheduc.2006.06.005

[60] Gayton, J. and McEwen, B.C.(2007).Effective online instructional and assessment strategies. The American Journal of Distance Education, vol. 21, no. 3, pp. 117-132.

[61] Graham, Charles, Cagiltay, Kursat, Lim, Byung-Ro, et al. (2001).Seven principles of effective teaching: A practical lens for evaluating online courses. The technology source, vol. 30 , no. 5 , pp. 50 .

[62] Levy, Y.(2008).An empirical development of critical value factors (CVF) of online learning activities: An application of activity theory and cognitive value theory. Computers \& Education, 51(4), 1664-1675. https://doi.org/10.1016/j.compedu.2008.04.003

[63] Grimmer-Somers, K., S. Milanese, and L. Chipchase. (2011)."Research into Best Practices in e-Learning for Allied Health clinical education and training." Brisbane: Clinical Education and Training Queensland. 
Paper-Identification and Learning Styles' Variation Factors for a Hybrid and Distance Learning...

[64] Elkaseh A, Wong KW, Fung CC.(2014).The Impact of Teaching and Learning Styles on Behavioural Intention to Use E-learning in Libyan Higher Education. International Review of Contemporary Learning Research, Vol. 3, no.1, pp. 25-34. https://doi.org/10.12785 $\underline{\text { irclr } / 030103}$

\section{Authors}

Mostafa Hamse is a Phd student at the Laboratory of analytical chemistry and physio chemistry of materials, Faculty of Sciences Ben M'SIK, Hassan II University, Casablanca. He works as a teacher trainer at the Regional Center of Education and Training Professions in Casablanca, Morocco.

Said Lotfi is a Phd Professor in Normal Superior School (ENS), Hassan II University of Casablanca(UH2C), BP 50069, Ghandi,Casablanca. He is a member in the Multidisciplinary Laboratory in Education Sciences and Training Engineering, Casablanca, Morocco.

Mohammed Talbi is a Phd Professor in Faculty of Sciences Ben M'SIK, Hassan II University, Casablanca.He is the director of Observatory of Research in Didactics and University Pedagogy (ORDIPU). He is the Dean of the Faculty of Science Ben M'sik Hassan II University, Casablanca, Morocco.

Article submitted 2020-12-31. Resubmitted 2021-06-11. Final acceptance 2021-06-11. Final version published as submitted by the authors. 